\title{
Constraints in Using Kisan Mobile Advisory Service as Perceived by Farmers in Banaskantha District of Gujarat, India
}

\author{
K.V. Patil ${ }^{1 *}$, V.T. Patel $^{2}$ and R.R. Prajapati ${ }^{2}$ \\ ${ }^{1}$ Department of Agricultural Extension, PJTSAU, Hyderabad, Telangana -500030, India \\ ${ }^{2}$ Department of Extension Education, SDAU, Sardarkrushinagar, Gujarat -385506, India \\ *Corresponding author
}

\section{A B S T R A C T}

\begin{tabular}{|l|}
\hline K e y w or d s \\
$\begin{array}{l}\text { Farmer-subscribers, } \\
\text { Agricultural } \\
\text { information, KMAS. }\end{array}$ \\
\hline Article Info \\
\hline $\begin{array}{l}\text { Accepted: } \\
\text { 04 September } 2017 \\
\text { Available Online: } \\
\text { 10 November } 2017\end{array}$ \\
\hline
\end{tabular}

Information Communication Technology (ICT) is today becoming as important as food. Even in rural India, ICTs are having a profound impact in changing the rationale of development activities and strategies. Inspite of these farmers abstain from using it due to various constraints. In this view, a study was conducted to analyze constraints faced by farmers in using KMAS in Banaskantha district of Gujarat state, India. A total of 123 respondents constituted sample size were selected through multistage sampling technique. The data collection was done with the help of structured schedule by personal interview of the respondents. Results of the study revealed that majority (70.73 per cent) of farmers reported that understanding of the message become difficult, if any doubt arises followed by difficult to understand technical words in the message (63.41 per cent) and skill oriented messages could not be understood through text message (57.72 per cent). The study recommends the need for considering constraints faced by farmers as they influence the accessibility and utilization pattern of KMAS.

\section{Introduction}

Information

and

Communication

Technologies (ICTs) are facilitating faster sharing of information and innovations and acting as a key agent for changing agrarian situation and farmers lives by improving access to information and sharing knowledge. The information and communication technologies like radio, TV, newspaper, telephone and magazines are playing a major role in agricultural development since early decades. Now the modern Information Communication Technologies (ICTs) as mobiles and computers have created an information revolution. In the $21^{\text {st }}$ century, cost effective and efficient communication technologies are required to take lead in changing agricultural scenario.

The government has a huge research and development infrastructure in the form of institutions such as the Indian Council of Agricultural Research (ICAR), State Agricultural Universities (SAUs), Krishi Vigyan Kendras (KVKs) and Agriculture Technology Management Agencies (ATMAs). The role of this set-up in research and extension activity is of great importance. The use of Kisan Mobile Advisory Service (KMAS) scheme in front line extension system of Krishi Vigyan Kendra's is new ICT 
initiatives to meet the information needs and expectations of the farmers.

KMAS is started by ICAR with the aim of passing the agricultural information to maximum number of farmers in local language through SMS free of cost. It is operated by KVKs all over the India. Subject areas of KMAS are Agronomy, Plant protection, Horticulture, Animal science, Home science, Dairy, etc. Advantages of KMAS are farmers can get free information, location specific information delivery, provide information in local language and cost effective. KMAS has been launched in $192 \mathrm{KVKs}$ all over India and KVK Deesa is one of the KVK selected for implementation of scheme. KVK is using Kisan Portal, Ministry of Agriculture, Government of India to send the SMS to the farmers.

Information Communication Technology (ICT) is today becoming as important as food. Even in rural India, ICTs are having a profound impact changing the rationale of development activities and strategies. Inspite of these farmers abstain from using it due to various constraints. A national survey of farmers found that only 40 per cent of farmer households accessed information about modern agricultural techniques and inputs (NSSO, 2005). So keeping these points in mind the study was mainly focused to reveal the constraints associated with use of KMAS by the farmers of Banaskantha district.

\section{Materials and Methods}

\section{Description of study area}

The study was conducted in Banaskantha district of Gujarat state. It is the third largest district of Gujarat and is located in North Eastern region of the state at altitude of $23.33^{\circ}$ to $24.45^{\circ}$ North and Longitude of $71.03^{\circ}$ to $73.02^{0}$ East. It is surrounded by Mehsana district in the south, Sabarkantha district in the east, Patan district in the west and Jalor and Sirohi regions of the Rajasthan state in the north. The North part of the Sabarkantha district has common boundary with Banaskantha district and Rajasthan State. The region is presumably named after the Banas River. The average annual rainfall is $684 \mathrm{~mm}$. The temperature ranges from a maximum of $33.8^{0} \mathrm{C}-36.8^{0} \mathrm{C}$ to minimum of $8.8^{0} \mathrm{C}-12^{\circ} \mathrm{C}$. The irrigation facility of the district consists of 3 dams, $220 \mathrm{~km}$ canals and 43714 wells.

\section{Sampling technique}

The study was confined to ex-post facto research design as the independent variables have already made impact on utilization of ICT that was studied by the researcher (Kerlinger, 1976). Multi stage sampling technique was employed in the study. The study was conducted in Banaskantha district of Gujarat state, where Krishi Vigyan Kendra (KVK) is providing agricultural technological knowledge through KMAS. KVK Deesa is selected by ICAR for mobile advisory services among $192 \mathrm{KVKs}$ selected in first phase since 2009. The area of work of KVK Deesa is Banaskantha district, hence it was selected purposively. Banaskantha district comprises of 14 talukas. Out of these six talukas were purposively selected on the basis of more number of subscriber farmers of KMAS. Three villages from each selected taluka were purposively selected on the basis of higher number of subscriber farmers of KMAS. Village wise list of subscriber farmers was obtained from KVK Deesa.

Random sampling method was used in selection of respondents in proportion to 30 per cent of the subscribers from each selected village. Finally, a sample of 123 farmers was drawn from the population. The data were collected with the help of structured schedule by personal interview of the respondents. 


\section{Results and Discussion}

With respect to the constraints faced by the farmers, it was observed from the Table 1 that majority (70.73 per cent) of farmers reported clarification of the message is difficult, if any doubt arises was the foremost constraint in using KMAS. This was because there was no feedback cell or helpline centre, except the farmer make a return call to KVK scientist and it involve cost to the farmer. Difficult to understand technical words in the message (63.41 per cent) was the second most serious constraint. This was because majority of farmers having primary level education, hence unable to understand even some simple technical words frequently used in agriculture.
Practical oriented messages could not be understood through text message (57.72 per cent) was the third constraint.

This was due to the limitation of KAMS technology for sending visuals, hence it might have become difficult to understand the process through text message.

Whereas, information is sometime not relevant (39.02 per cent), poor network connectivity (21.95 per cent), SMSs were not timely (15.45 per cent), difficult to operate mobiles (11.38 per cent), irregular charging of mobile due to electricity problem (07.32 per cent) and adoption of KMAS messages is risky (05.69 per cent) were the less important constraints faced by the farmers.

Table.1 Distribution of the farmer-subscribers of KMAS according to the constraints faced in using KMAS ( $\mathrm{n}=123)$

\begin{tabular}{|l|l|c|c|c|}
\hline Sr. No. & \multicolumn{1}{|c|}{ Statements } & \multicolumn{2}{|c|}{ Yes } & Rank \\
\cline { 3 - 4 } & & Frequency & Percentage & \\
\hline 1. & $\begin{array}{l}\text { Clarification of the message is difficult if } \\
\text { any doubt arises. }\end{array}$ & 87 & 70.73 & I \\
\hline 2. & $\begin{array}{l}\text { Difficult to understand technical words in } \\
\text { the message. }\end{array}$ & 78 & 63.41 & II \\
\hline 3. & $\begin{array}{l}\text { Practical oriented messages could not be } \\
\text { understood through text message. }\end{array}$ & 71 & 57.72 & III \\
\hline 4. & Information is sometime not relevant. & 48 & 39.02 & IV \\
\hline 5. & Poor network connectivity. & 27 & 21.95 & V \\
\hline 6. & KMAS SMSs were not timely. & 19 & 15.45 & VI \\
\hline 7. & Difficult to operate mobile Phone. & 14 & 11.38 & VII \\
\hline 8. & $\begin{array}{l}\text { Irregular charging of mobile due to } \\
\text { electricity problem. }\end{array}$ & 09 & 07.32 & VIII \\
\hline 9. & Adoption of KMAS messages is risky. & 07 & 05.69 & IX \\
\hline
\end{tabular}

Though these constraints were face by less number of farmers but might be due to the fact that Banaskantha district is largest district in state having varied geography including desert in the west hilly tribal truck in the east.

These are diversified cropping sequence in the district. A critical analysis of constraints as perceived by farmers in using KMAS that majority (70.73 per cent) of farmers reported clarification of the message is difficult, if any doubt arises followed by difficult to understand technical words in the message (63.41 per cent) and practical oriented messages could not be understood through text message (57.72 per cent) were the major 
constraints faced by the farmers and ranked I, II and III, respectively.

These constraints can be overcome by providing feedback cell in KMAS regarding the services, replacing technical words with the local words by KMAS agent. To overcome the problem of irrelevant information need assessment of farmers should be done by KMAS agent and based on their need appropriate information should be given. The information provided by KMAS must be up to date. The network area should be extended to the rural as well as remote area.

\section{Acknowledgement}

I would like to thank my chairperson Dr. V. T. Patel for guiding me throughout my research study. I thank Department of Extension Education, SDAU, Sardarkrushinagar for allowing me to pursue my research study. I thank all the farmers who gave suitable information for the research study.

\section{References}

Kerlinger. 1976. Foundation of Behavioral Research. Surjeet Publication, Delhi. pp. 129.

NSSO. 2005. Situation assessment survey of farmers: Access to modern technology for farming. National sample survey, 59th round report, 499 (59/33/2). New Delhi: GOI. Retrieved on 14.05.2013 http://www.ifpri.org/sites/default/public ations/ifpride00729.pdf

Patil, K.V., 2016. Utilization pattern of Kisan Mobile Advisory Service by the farmers of Banaskantha district. M.Sc. Thesis. Sardarkrushinagar Dantiwada Agricultural University, Sardarkrushi nagar (India).

\section{How to cite this article:}

Patil, K.V., V.T. Patel and Prajapati, R.R. 2017. Constraints in Using Kisan Mobile Advisory Service as Perceived by Farmers in Banaskantha District of Gujarat, India. Int.J.Curr.Microbiol.App.Sci. 6(11): 237-240. doi: https://doi.org/10.20546/ijcmas.2017.611.028 